\title{
High organic loading rate and waste stabilization pond's operation efficiency: a case study
}

\author{
Sh. Jamshidi ${ }^{1}$, G. B Gholikadi ${ }^{1}$ \& H. R. Orumieh ${ }^{2}$ \\ ${ }^{I}$ Power and Water University of Technology (PWUT), Tehran, Iran \\ ${ }^{2}$ Pars Arianab Consulting Engineers, Isfahan, Iran
}

\begin{abstract}
Liquid waste management is an important component of sanitation activities. Waste stabilization pond system is very low cost, easy for maintenance and the stabilized water outflowing from the system can be used for irrigation purposes in agriculture, horticulture, etc. The affect of high organic loading rate and occurrence reasons of purple sulfur bacteria (PSB) in waste stabilization ponds were investigated. Chemical parameters which affect on PSB growth like COD, and hydrogen sulfide $\left(\mathrm{H}_{2} \mathrm{~S}\right)$ were observed monthly. The mixed culture populations of PSB were considered and determined by spectro-photometric method. The cell suspension was whitish pink when elemental sulfur globules occurred inside the cells, and turned purplish red once the globules were consumed. The measurement of flow was carried out by means of a Partial flume in which located at the inlet channel. Measurement of flow was done simultaneously with wastewater sampling. The measured average of COD concentration of raw wastewater with around $1520.33 \mathrm{mg} / \mathrm{l}$ was much higher than the expected design concentration of $550 \mathrm{mg} / \mathrm{l}$, respectively, for COD. Thus, the raw wastewater in Hoveizeh can be classified as a high strength in terms of COD. Results showed that the PSB dominated in two periods, which the first was in midsummer (in primary facultative pond) and the second was in midwinter (in tertiary facultative pond). This condition was occurred by high organic loading rate (OLR) and high concentration of $\mathrm{H}_{2} \mathrm{~S}$ which were caused overcoming of the PSB over algae. Results showed that the OLR was the main affecting parameters in the overcoming of PSB. It could be suggested that by
\end{abstract}


upgrading the capacity of the Hoveizeh facility (constructing parallel ponds), the problem caused by the purple sulfur bacteria could be dominantly reduced.

Keywords: waste stabilization pond, operation, $\mathrm{OLR}, \mathrm{COD}, \mathrm{H}_{2} \mathrm{~S}$, purple sulfur bacteria.

\section{Introduction}

Waste stabilization ponds (WSPs) are considered the most appropriate way to treat the increasing flows of urban wastewater in tropical and subtropical regions of the world. WSPs are commonly used as efficient means of wastewater treatment relying on little technology and minimal albeit regular, maintenance. Their low capital and hydraulic loads have been valued for years in rural regions and in many countries wherever suitable land is available at reasonable cost [15]. The treatment occurring in the WSP results from the complex symbiosis of bacteria and algae species which results in an ecological pattern different from that of these organisms grown in pure culture. Periodic change of $\mathrm{pH}$, temperature, and light intensity controls the abundance and activity of specific groups of micro-organisms in the multi-species microbial communities' characteristic of ponds [6-9]. The natural origin of the phenomena which cause treatment in the WSPs does not make them easier to study or to understand, especially when it is a case of applying them to the design of the installations. Among the most complex phenomena, growth of purple sulfur bacteria (PSB) is prevalent in ponds which cause the wastewater color becomes red [10-12]. The effluent quality was lower than expected with color intensity (red color), smell and high-suspended solid concentrations [13].

PSB represent a physiological group of unicellular gram-negative bacteria phylogenetically classified in the class Gammaproteobacteria within the order Chromatiales [14]. They are ubiquitously distributed but restricted to aquatic habitats characterized by adequate light conditions, low oxygen tension, and moderate sulfide concentrations. Under optimal conditions in nature, PSB form visibly colored blooms. The color is due to large amounts of carotenoids and bacteriochlorophylls, which are located in internal membranes. The most characteristic feature of all PSB is their ability to perform photosynthesis under anoxic condition, mainly using reduced sulfur compounds such as $\mathrm{H}_{2} \mathrm{~S}$ or thiosulfate as electron donors [15]. PSB represent a phylogenetic group that is clearly separated from all other anoxygenic photosynthetic bacteria, including the known gammaproteobacterial AAPB Congregibacter litoralis KT71 and strain HTCC2080 [16]. Many species of chromaticeae, the PSB, are actually purple, but others may be dark orange to brown or various shades of pink or red. PSB may grow in any aquatic environment to which light of the required wavelength penetrates, provided that carbon dioxide, nitrogen, and a reduced form of sulfur, or hydrogen, are available. PSB occupy the anaerobic layer below the algae, cyanobacteria, and other aerobic bacteria in a pond. Wavelength of light used by the PSB are different from those used by the cyanobacteria or algae; thus the sulfur bacteria are able to grow using light that has passed through the surface layer of water or sediment occupied by aerobic 
photosynthetic organisms. PSB are commonly found at a specific depth, in a thin layer where light and nutrition conditions are optimum. Conversion of odorous sulfide compounds to elemental sulfur or sulfate by the sulfur bacteria is a significant factor for odor control in facultative and anaerobic ponds [17]. PSB are commonly encountered in anoxic environments that contain hydrogen sulfide and are exposed to light [18]. Massive growth of PSB is often macroscopically visible in the environment because of the high intracellular content of pigments in these organisms. These blooms are, in effect, natural enrichment cultures that allow physiological studies in the environment to be carried out. [19]. Numerous researchers have documented the presence of PSB (Family Chromatiaceae) in anaerobic ponds, particularly those treating sulphide-bearing wastewaters. Cooper found Thiopedia rosea in an anaerobic pond receiving rendering plant waste and Chromatium sp. in an anaerobic pond receiving petroleum refinery waste. Neither pond produced any odors. When the loading to the ponds was increased, the ponds turned pink but still provided a reasonable degree of wastewater treatment. Meredith and Pohland found Chromatium sp. to be the dominant bacteria in cultures obtained from a pink pond receiving poultry processing wastes. The optimum temperature and $\mathrm{pH}$ for these bacteria were $26.5^{\circ} \mathrm{C}$ and 7.5 , respectively. Iron limited the rate at which they oxidized hydrogen sulphide. High concentrations of Rhodothece were observed in a red swine nutrition farm pond by Sletten and Singer (Meredith and Pohland [20]). McFarlane and Melcer found Thiocapsa roseopersicina and Chromatium sp. in anaerobic ponds treating meat packing, piggery, fellmongery (dehairing) and municipal wastewaters [20]. Thiocapsa roseopersicnia was also found by Van Lotringen and Gerrishs in lagoons receiving swine waste [21]. Wenke and Vogt identified Thiopedia rosea as the dominant bacterium in an anaerobic lagoon receiving cattle feedlot drainage [22]. The presence of PSB in anaerobic ponds is beneficial for several reasons. First, by utilizing hydrogen sulphide as an electron donor for photosynthesis, these bacteria remove the principal cause of odor nuisances which otherwise plague anaerobic ponds. Finally, it has been found that these bacteria are effective in the removal of toxic amine compounds and produce anti-viral substances. Although anaerobic ponds are capable of substantial reductions in waste organics, effluents of ponds supporting the growth of PSB still contain relatively high nutrient levels, in addition to high concentrations of bacterial biomass. Lincoln and Hill and Koopman, Lincoln and Nordstedt have studied the use of photosynthetic oxygenation for further treatment of effluent from an anaerobic pond receiving swine wastes [23]. The photosynthetic oxygenation process is advantageous since, in addition to producing an effluent with acceptable water quality in terms of nutrient levels, it also yields a high-protein by-product (algal biomass). However, the bacterial solids present in pond effluent interfere with transmission of light to algal cells, decreasing photosynthetic oxygenation rates. In the studies cited above, the first channel of a shallow, channelized pond system was utilized as a sedimentation basin for removal of Thiopedia rosea cells prior to the introduction of pond effluent into the remainder of the system. Substantial removal of T. rosea was obtained, as evidenced by the deposition of a sludge layer over the channel's 
bottom. Microscopic examination of the sediment revealed the presence of floe particles, and it was hypothesized that the T. rosea bioflocculated in response to the change in environmental conditions caused by their transfer from the pond to the first pond channel.

In this study, chemical and biochemical parameters were monitored during the PSB growth and relationship between those parameters and PSB was investigated. Also, the operation performance of the southern WSP (SWSP) of Hoveizeh was surveyed and upgrading viewpoints were also considered for problems related to PSB growth.

\section{Methodology}

\subsection{Site specification}

Hoveizeh city is located in the south of Susangerd city, $15 \mathrm{~km}$ distance from that. The latitudinal location of the Hoveizeh city is about $48^{0} \mathrm{~N}$, the longitude is around $31^{\circ} \mathrm{E}$ and the altitude reaches from $17-20 \mathrm{~m}$ above sea level. Nissan River, a branch from Karkheh River, divided the city into northern and southern areas which two WSPs had been constructed in each area. The southern WSPs began its operation in 1985 for the equivalent populations of 9000 and final populations of 21000 (25 years later). The SWSP comprises two anaerobic ponds in parallel followed by one primary, secondary, and tertiary facultative pond (Figure 1) and treated wastewater of the facility is used for agricultural reuse.

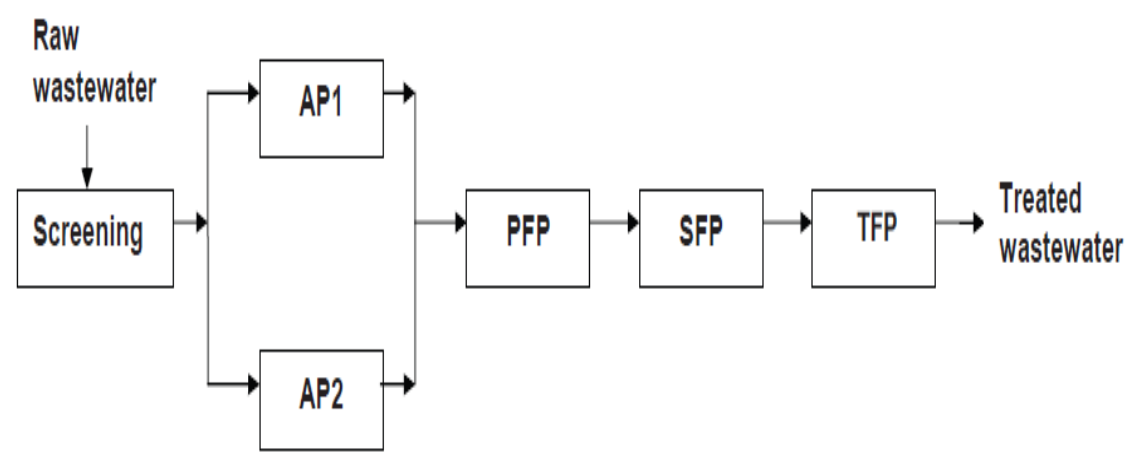
$\mathrm{AP}=$ Anaerobic Pond
$\mathrm{PFP}=$ Primary facultative Pond
$\mathrm{SFP}=$ Secondary facultative Pond
TFP $=$ Tertiary Facultative Pond
DT=Distribution Tank

Figure 1: Schematic flow diagram of wastewater stabilization ponds of Hoveizeh. 


\subsection{Climate}

Hoveizeh city has a relatively hot and sultry climate. The maximum temperature may rise up to 51 degrees Celsius in summer and may fall to below -3 degrees Celsius in winter. The average temperature in the coldest month is 7.6 degrees Celsius .The average precipitation is around $7 \mathrm{~mm} /$ year and the annual relatively humidity is 59.31 percent. As can be seen in figure 1, the SWSP is the same as classical pond configurations with anaerobic ponds and facultative ponds. Table 1 presents the physical and operational characteristics of the SWSP systems.

Table 1: $\quad$ Physical and operational characteristics of the SWSP system.

\begin{tabular}{cccc}
\hline component & Area $\left(\mathrm{m}^{2}\right)$ & Depth $(\mathrm{m})$ & Volume $\left(\mathrm{m}^{3}\right)$ \\
\hline $\begin{array}{c}\text { Anaerobic pond 1 } \\
\text { (AP1) }\end{array}$ & 1102.5 & 3.5 & 2756 \\
$\begin{array}{c}\text { Anaerobic pond } 2 \\
\text { (AP2) }\end{array}$ & 1102.5 & 3.5 & 2756 \\
$\begin{array}{c}\text { Total Anaerobic } \\
\text { Primary facultative } \\
\text { pond (PFP) }\end{array}$ & 2205 & - & 5152 \\
$\begin{array}{c}\text { Secondary } \\
\text { facultative pond } \\
\text { (PFP) }\end{array}$ & 4225 & 3.5 & 10562.5 \\
$\begin{array}{c}\text { Tertiary facultative } \\
\text { pond (TFP) }\end{array}$ & 4225 & 3.5 & 10562.5 \\
\hline $\begin{array}{c}\text { Total facultative } \\
\text { Total }\end{array}$ & 4225 & 3.5 & 10562.5 \\
\hline
\end{tabular}

Daily treated flow: $2250 \mathrm{~m}^{3}$.

\subsection{Sampling}

The data of samples were based on a thesis which had been done on wastewater stabilization ponds of Hoveizeh [24]. Wastewater samples were taken at the inlet and the outlet of each pond, monthly. The collected samples were composite samples taken over a period of 48 hours. The samples were taken directly by means of $2 \mathrm{~L}$ beaker glass. Each sample of $2 \mathrm{~L}$ was taken from depth of $1 \mathrm{~m}$, directly transferred to a $30 \mathrm{~L}$ sample container and stored in $4^{\circ} \mathrm{C}$ till further physicochemical analyses [25].

\subsection{Analyzed parameters}

These included total chemical oxygen demand (COD), Hydrogen Sulfide $\left(\mathrm{H}_{2} \mathrm{~S}\right)$, and SOLR. The mixed culture populations of PSB were considered and determined by spectro-photometric method. The living cell suspension of the 
purple sulfur bacterium had absorption maxima characteristic of bacteriochlorophyll a $(380,590,830$, and $890 \mathrm{~nm})$. The cell suspension was whitish pink when elemental sulfur globules occurred inside the cells, and turned purplish red once the globules were consumed. The absorption maximum of $520 \mathrm{~nm}$ suggested that the bacterium contained okenone as the main carotenoid [26]. The measurement of flow was carried out by means of a Partial flume in which located at the inlet channel. Measurement of flow was done simultaneously with wastewater sampling. The techniques used in this study were following Standard Methods [27].

\section{Results and discussion}

The results were obtained by each stage and by the total systems in the period of the study, as presented in Table 2. The measured average of COD concentrations of raw wastewater with around $1520.33 \mathrm{mg} / \mathrm{l}$ was much higher than the expected design concentration of $550 \mathrm{mg} / 1$, respectively, for COD. Thus, the raw wastewater in Hoveizeh can be classified as a high strength in terms of COD [28].

Table 2: The averages and percentage removal of the parameters in the SWSP of Hoveizeh.

\begin{tabular}{ccc}
\hline & & COD $(\mathrm{mg} / \mathrm{L})$ \\
\hline \multirow{2}{*}{ AP } & Inf & 1520.33 \\
& Eff & 637.50 \\
& \%Rem & 58.07 \\
PFP & Inf & 637.50 \\
& Eff & 637.83 \\
& \%Rem & -0.05 \\
SFP & Inf & 637.83 \\
& Eff & 503.83 \\
& \%Rem & 21.01 \\
\multirow{2}{*}{ TFP } & Inf & 503.83 \\
& Eff & 523.17 \\
Total & $\%$ Rem & -3.84 \\
\hline
\end{tabular}

This study was conducted in three seasons and the growth of PSB was occurred between July to September. The average air temperature in this period was $25.4^{\circ} \mathrm{C}$, however the average air temperature on august was $32^{\circ} \mathrm{C}$ and the maximum value was $50^{\circ} \mathrm{C}$. Hence, more evaporation and $\mathrm{DO}$ reduction (by 
increasing the activity of microorganisms) were occurred, which are important parameters affecting on PSB growth. Moreover, by air temperature increasing, the activity of algae has been decreased which was intensifying the problems related to PSB growth.

The surface and volume OLR increased significantly (about twice) because the AP1 and AP2 were out of work, respectively for maintenance, sludge discharge and digestion.

The PSB growth is highly related to the $\mathrm{H}_{2} \mathrm{~S}$ concentration. The COD concentration has a relatively strength relation with the $\mathrm{H}_{2} \mathrm{~S}$ concentration $\left(\mathrm{r}^{2}=0.77\right.$ for COD) which means that the $\mathrm{H}_{2} \mathrm{~S}$ parameter has a direct relation with the COD and could be considered as important inhibitors for algae growth in facultative ponds (Figure 2). The number of PSB in the oxidation pond increased while the sulfide and volatile fatty acid concentrations in the wastewater decreased $[12,30,31]$.

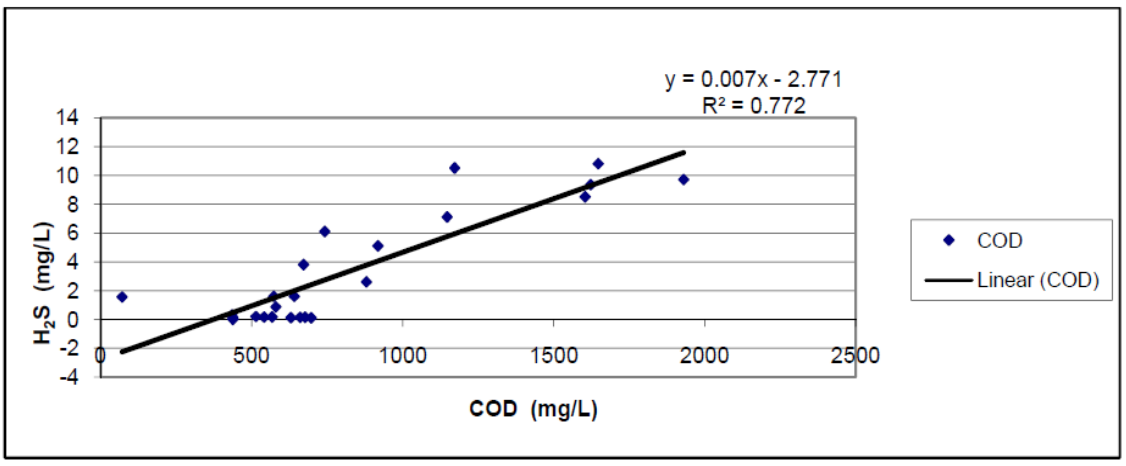

Figure 2: Relationship between $\mathrm{COD}$ and $\mathrm{H}_{2} \mathrm{~S}$ in SWSP of Hoveizeh.

The PSB growth was occurred in 2 periods in the study (July to August and November to December) which the PFP and SFP were involved by the first phenomenon and the second was just involved the TFP. The PSB intense growth could be clearly detected by color change of ponds from green to red. It is noteworthy to say that by increasing the PSB growth, methanogenic processes were increasing considerably in facultative ponds and led the ponds to anaerobic phase [12].

As noted above, the domination of the PSB in stabilization ponds is related to the $\mathrm{H}_{2} \mathrm{~S}$ concentration and that is also related to the COD concentration. One of the main reasons of PSB growth in the SWSP of Hoveizeh was the SOLR (Surface organic loading rate) which was often more than the design considerations (Table 3). Results showed that the OLR had been more than expected values which was significantly increased on October to December. However, the PSB population was then decreased because the $\mathrm{H}_{2} \mathrm{~S}$ concentration was getting lower (due to continuing high OLR in the constant $\mathrm{H}_{2} \mathrm{~S}$ concentration). Houghton and Mara [11] found that the increasing of organic loading in primary stabilization pond reduced the number of algae and increased 
the number of PSB. The hydrogen sulfide concentration in the high-rate photosynthetic wastewater treatment plant was increased due to the death of algae and the domination of PSB [12, 29, 30].

Table 3: $\quad$ SOLR and average air temperature of SWSP of Hovaizeh.

\begin{tabular}{|c|c|c|c|}
\hline \multirow[t]{2}{*}{ Month } & SOLR & SOLR & \multirow{2}{*}{$\begin{array}{c}\text { Average air } \\
\text { temperature }\left({ }^{\circ} \mathrm{C}\right)\end{array}$} \\
\hline & $\begin{array}{c}\text { Design condition } \\
\mathrm{kgBOD} / \mathrm{ha} . \mathrm{d}\end{array}$ & $\begin{array}{c}\text { Real condition } \\
\mathrm{kgBOD} / \mathrm{ha} \text {.d }\end{array}$ & \\
\hline \multicolumn{4}{|c|}{ PFP } \\
\hline July & 455 & 362 & 31 \\
\hline August & 474 & 714 & 32.3 \\
\hline September & 394 & 748 & 27.3 \\
\hline October & 340 & 715 & 24.5 \\
\hline November & 285 & 799 & 21.7 \\
\hline December & 212 & 1369 & 17.75 \\
\hline \multicolumn{4}{|c|}{ SFP } \\
\hline July & 470 & 250 & 32 \\
\hline August & 481 & 382 & 32.9 \\
\hline September & 388 & 387 & 27 \\
\hline October & 301 & 634 & 22.5 \\
\hline November & 252 & 524.5 & 19.95 \\
\hline December & 182 & 1092 & 16 \\
\hline \multicolumn{4}{|c|}{ TFP } \\
\hline July & 453 & 287.5 & 30.8 \\
\hline August & 470 & 214 & 32 \\
\hline September & 378 & 326 & 26.45 \\
\hline October & 372 & 502 & 26.14 \\
\hline November & 216 & 407 & 17.95 \\
\hline December & 170 & 684 & 15.2 \\
\hline
\end{tabular}

\section{Conclusion}

Purple sulfur bacteria have long been associated with anaerobic, sulfidecontaining zones in lakes and more recently these organisms have been associated with treatment facilities. Our data show that T. floridana and C. vinosum have the capabilities of utilizing many organic substrates, especially as electron donors. These data indicate that purple sulfur bacteria have the enzymatic capability for utilization of organic substrates, many of which are found in a lagoon. For solving the problem related to the PSB growth, the main way is to reduce the OLR in ponds. However, the SLR (Solid Loading rate) would increase and thus the problem remains. The best way for the SWSP of Hoveizeh is to construct new ponds in parallel to AP, PFP, SFP and TSP to divide the OLR and SLR in ponds and therefore achieving higher treatment efficiency and also better performance of ponds. 


\section{Acknowledgement}

The authors acknowledged the Power and Water University of Technology (PWUT) for their supports of this study.

\section{References}

[1] Agunwamba, J. C. (2001) Effect of tapering on the performance of waste stabilization ponds. Water Res., 35, 1191-1200.

[2] Hamdy, A., Rabia, N., Hamdy, S. (2006) Study of waste stabilization pond geometry for wastewater treatment efficiency. Ecolo. Eng., 28, 25-34.

[3] Kaya, D., Dilek, F., Gokcay, C.F. (2007) Reuse of lagoon effluents in agriculture by post-treatment in a step feed dual treatment process. Desalination, 215, 29-36.

[4] Nameche, T., Vasel, J. L. (1998) Hydrodynamic studies and modelization for aerated lagoons and waste stabilization ponds. Water Res., 32, 30393045.

[5] Nelson, K. L. et al. (2004) Sludge accumulation, characteristics, and pathogen inactivation in four primary waste stabilization ponds in central Mexico. Water Res., 38, 111-127.

[6] Badalians Gholikandi, G. (2009) Wastewater treatment plant design. 1st ed., Ajeez Tehran.

[7] Kayombo, S., Mbwette, T.S.A., Mayo, A.W., Katima, J.H.Y., Jorgensen, S.E. (2002) Diurnal cycles of variation of physical-chemical parameters in waste stabilization ponds. Ecol. Eng., 18, 287-291.

[8] Murakani, K. et al. (1992) Effect of temperature on prosperity and decay of genetically engineered micro-organisms in a microcosm system. Water Sci. Technol., 26, 2165.

[9] Wilderer, P. A. et al. (1991) Impact of the addition of pure cultures on the performance of mixed culture reactors. Water Res., 25, 1307-1313.

[10] Alabaster, G. P. (1991) Combined treatment of domestic and industrial wastewater stabilization pond systems in Kenya. Water Sci. Technol., 24, 43-52.

[11] Houghton, S. R., Mara, D. D. (1992) The effects of sulfide generation in waste stabilization ponds on photosynthetic populations and effluent quality. Water Sci. Technol., 26, 1759-1768.

[12] Sirianuntapiboon, S., Srikul, M. (2006) Reducing red color intensity of seafood wastewater in facultative pond. Bioresource Technol., 97, 16121617.

[13] Nair, C. (1992) Pollution control through water conservation and wastewater reuse in the fish processing industry. Water Sci. Technol., 22, 113-121.

[14] Imhoff, J. F. (2005) Order I.Chromatiales ord. nov., in Bergey's manual of systematic bacteriology. edited, Springer, New York.

[15] Tank, M. et al. (2009) Phylogenetic relationship of phototrophic purple sulfur bacteria according to pufL and pufM gens. Int. Microbiol., 12, 175-185. 
[16] Cho, J. C., Stapels, M.D., Morris, R.M. (2007) Polyphyletic photosynthetic reaction center gens in oligotrophic marine Gammaproteobacteria. Environ Microbiol, 9, 1456-1463.

[17] U.S.EPA (1983) Design manual for municipal wastewater stabilization ponds. NSCEP.

[18] Guyoneaud, R., Matheron, R., Liesack, W., Imhoff, J.F., Caumette, P. (1997) Thiorhodococcus minus, gen. nov., sp. nov., a new purple sulfur bacterium isolated from coastal lagoon sediments. Arch Microbiol., 168, 16-23.

[19] Casamayor, E. O., Mas, J., Pedro's-Alio, C. (2001) In Situ Assessment on the Physiological State of Purple and Green Sulfur Bacteria through the Analyses of Pigment and 5S rRNA Content. Microb. Ecol., 42, 427-437.

[20] Meredith, J., Pohland, F. (1970) Some observations \& of purple sulfur bacteria associated with waste stabilization ponds. Purdue Eng. Ext. Ser., 137, 699-707.

[21] Van Lotringen, T., Gerrish, J. (1978) $\mathrm{H}_{2} \mathrm{~S}$ removal by purple sulfur bacteria in swine waste lagoons. paper presented at 33rd Industrial Waste Conference, Purdue University.

[22] Wenke, T., Vogt, J. (1981) Temporal changes in a pink feedlot lagoon. Appl. Environ. Microb., 41, 381-385.

[23] Lincoln, E., Hill, D. (1980) An integrated microalgae system. In G. Shelef and C. J. Soeder (Eds) Algae Biomass, Elsevier/North-Holland Biomedical Press, Amsterdam.

[24] Sakian Dezfouli, M. R., Badalians Gholikandi, G. (2007) Investigation of Periodical Decrease of the Effluent Quality of Wastewater Stabilization Ponds of Hoveizeh. 169 pp, Power and Water University of Technology (PWUT), Tehran.

[25] Yaghoubi, M., Echihabi, L., Foutlane, A., Bourchich, L., Jellal, J., Wittland, C., Yachioui. M. (2000) The performance of the waste stabilization pond system at Boujaad, Morocco. Water Sci. Technol., 42, 9-11.

[26] Matsuyama, M. (2004) Phylogenic status of a purple sulfur bacterium and its bloom in Lake Kaiike. Jpn. Soc. Limnol., 5, 95-101.

[27] APHA (2005) Standard Methods for the Examination of water and wastewater. 24th ed., American Public Health Association (APHA), Washington, D. C.

[28] Tchobanoglous, G., Burton, F. L. (2003) Wastewater Engineering: Treatment. Disposal and Reuse, McGraw Hill, New York.

[29] Guyoneaud, R., Wit, R.D., Matheron, R., Caumette, P. (1998) Impact of macroalgal dredging on dystrophic crises and phototrophic bacterial blooms (red waters) in a brackish coastal lagoon. Oceanol. Acta, 21, 551-561.

[30] Sinha, S. N., Banerjee, R. D. (1997) Ecological role of thiosulfate and sulfide utilizing purple non-sulfur bacterial of a riverine ecosystem. FEMS Microbiol. Ecol., 24, 211-220.

[31] Angelica, P. S., Tommy, H., Overmann, J. (1993) Physiology of purple sulfur bacteria forming macroscopic aggregates in Great Sippewissett Salt Marsh, Massachusetts. FEMS Microbiol. Ecol., 12, 225-235. 